\title{
Current Inventory-Sales Relationships
}

The SUSTAINED ECONOMIC EXPANSION of the 1960s has coincided with a declining interest in the inventory-accelerator theory of the business cycle. However, while inventories may have lived down their villainous role in the business cycle literature, they remain a major source of economic instability. And at least once-in 1966-67-they nearly ended the "Hallelujah Chorus" of the economic policy makers. In view of the weak performance of inventories in recent months and revisions in some of the historical data, a reexamination of the pattern of inventory accumulation in recent years may be instructive.

End-of-quarter inventories and quarterly sales for manufacturing and trade combined are shown in Figure 1. The straight line represents the average stock-sales relation from 1953 to 1965 . Two things stand out in this figure: the tremendous size of the excess inventory buildup that developed during 1966, and the curious fact that much of this rise in the inventory-sales ratio was not worked off subsequently.

The economic rebound in the second half of 1967 reflected either a fortuitous shift in the long-run relationship between inventories and sales or an impressive forecasting performance by those who early in that year predicted a strong expansion in the last half of the year. Under normal circumstances an adjustment of production nearly twice that observed would have been expected. Indeed that is the result that I obtained with the aggregate inventory equations currently being used in major models by the Wharton School, the Office of Business Economics, and the University of Michigan. While they all predict only about half of the actual inventory 
accumulation in late 1966, they imply substantially lower production in the second and third quarters of 1967. The 1966-67 events also may be a cause for future concern; for if the inventory-sales ratio can so abruptly and inexplicably move above the historical relationship, it might with equal abruptness return to it.

In attempting to trace the 1966 inventory buildup and the resulting longer-run increase in the inventory-sales ratio, I disaggregated the data into some of the major categories. This process made evident the concentration of the inventory buildup in durables. The inventory-sales ratio for nondurables rose only from 0.397 to 0.411 from spring 1966 to spring 1967 and returned to 0.40 early in 1968 (Table 1 ). In contrast, the ratio

\section{Figure 1. Manufacturing and Trade Inventories and Sales, by Quarter, ${ }^{a}$ 1961-69}

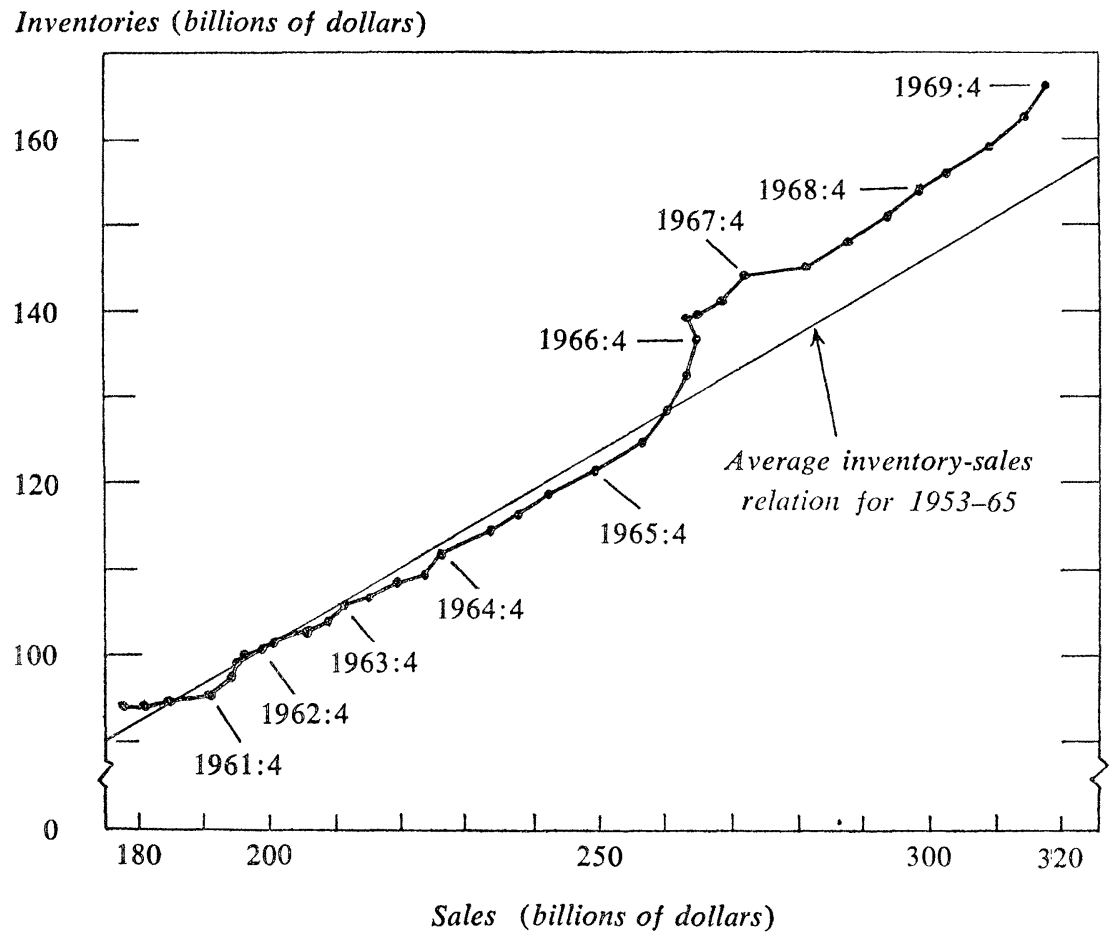

Source: U.S. Office of Business Economics.

a. Inventories are end-of-quarter book values; sales are those during the quarter. All data are seasonally adjusted. 
for durables jumped from 0.609 to 0.667 from spring 1966 to spring 1967, and stayed up around 0.65 consistently thereafter.

The concentration of large changes in the inventory-sales relationship within the more erratic category of durable goods manufacturing is not completely surprising. But nondurable goods were a more active contributor in past cycles and it is difficult to understand why the post-1966 rise in the overall ratio was limited to durables.

\section{Table 1. Manufacturing and Trade Inventory-Sales Ratios, by Stage of Manufacture and by Industry, Selected Dates, 1962-70}

Ratio of end-of-quarter inventories, book value, to sales during the quarter; seasonally adjusted

\begin{tabular}{|c|c|c|c|c|c|}
\hline Industry or stage & $\begin{array}{c}\text { Average } \\
1962: 1- \\
1966: 2\end{array}$ & $1966: 2$ & $1967: 2$ & $\begin{array}{c}\text { Average } \\
\text { 1968:1- } \\
\text { 1969:4 }\end{array}$ & $1970: 1^{\mathrm{a}}$ \\
\hline Total business & 0.497 & 0.495 & 0.528 & 0.516 & 0.526 \\
\hline $\begin{array}{l}\text { Total durable goods manufactur- } \\
\text { ing and trade }\end{array}$ & 0.609 & 0.609 & 0.667 & 0.648 & 0.679 \\
\hline $\begin{array}{l}\text { Total nondurable goods manu- } \\
\text { facturing and trade }\end{array}$ & 0.405 & 0.397 & 0.411 & 0.400 & 0.397 \\
\hline Durable goods manufacturing & 0.636 & 0.616 & 0.705 & 0.674 & 0.709 \\
\hline Automotive retail trade & 0.472 & 0.564 & 0.492 & 0.542 & 0.595 \\
\hline Other durables trade & 0.616 & 0.612 & 0.661 & 0.636 & 0.645 \\
\hline \multicolumn{6}{|l|}{$\begin{array}{l}\text { Durable goods manufacturing } \\
\text { Stage of fabrication }\end{array}$} \\
\hline Materials & 0.198 & 0.192 & 0.208 & 0.193 & 0.196 \\
\hline Goods in process & 0.267 & 0.269 & 0.319 & 0.312 & 0.331 \\
\hline Finished goods & 0.171 & 0.155 & 0.177 & 0.169 & 0.182 \\
\hline \multicolumn{6}{|l|}{ Industry } \\
\hline Defense & 0.843 & 0.850 & 1.003 & 0.979 & 1.043 \\
\hline $\begin{array}{l}\text { Consumer durables and } \\
\text { automotive }\end{array}$ & 0.416 & 0.423 & 0.462 & 0.491 & 0.559 \\
\hline Other durables & 0.691 & 0.652 & 0.741 & 0.675 & 0.684 \\
\hline
\end{tabular}

Source: U.S. Office of Business Economics.

a. Based on preliminary data for the first two months of the quarter.

In addition, the rise in the inventory-sales ratio shows up within all the major subcategories of durables. On the basis of the average ratio to sales for 1962-65, the levels of inventories in 1968-69 were higher than expected by $\$ 4$ billion in durable goods manufacturing, $\$ 1.2$ billion in automotive trade, and $\$ 0.75$ billion in the other durables trade. None of the overall rise in the ratio can be attributed to a shift in the distribution of sales among these sectors. 


\section{Movements within Durables Manufacturing}

The concentration of the rise in the overall ratio within durable goods manufacturing makes it worthwhile to examine this sector in greater detail. First, I disaggregated its inventories by three stages of fabricationmaterials, goods-in-process, and finished goods. While all three ratios rose substantially in the 1966-67 period, nearly all of the longer-run increase is accounted for by inventories of goods-in-process (Table 1). The behavior of inventories of raw materials is consistent with the rapid rise in new orders in the first three quarters of 1966 and may reflect some concern with the lengthening of deliveries on materials experienced early in the year.

However, the concentration of the major inventory changes within durable goods-in-process raises questions about the appropriateness of the stock adjustment approach to overall inventory accumulation. The stock adjustment view implies that businessmen set their sights on a target level of inventories, based on and moving with expected sales, and adjust their actual stock toward the shifting target when they are surprised by the actual course of sales. Empirically and analytically, the behavior of inventories of finished goods and raw materials corresponds well to a stock adjustment model. But inventories of goods-in-process necessarily behave differently. When their movements are important, as they were in 196667 , they must be treated separately.

An alternative approach to the inventory behavior of durables manufacturing is an examination of the major industry groups. I made a comparison between the inventory-sales ratios for 1962-66 and 1968-69 of the major sectors. A three-way division into defense industries, consumer durables, including automobiles, and all other durables is shown in Table 1.

This grouping provides some explanation of the post-1966 rise in the overall inventory-sales ratio. The shift in the sales mix toward industries with the higher ratios of inventories to sales (primarily toward defense and machinery and away from autos and primary metals) accounts for fully 50 percent of the rise in the ratio for durable goods manufacturing. In addition only defense and consumer durables exhibit a large and sustained rise in their ratios.

The first result reemphasizes the long period of production for defense goods and the extent to which the major economic impact of changes in such expenditures occurs well before they show up in the budget. For ex- 
ample, this anomaly of timing is responsible in part for the occasional negative findings about the efficacy of fiscal policy in very short-run changes in gross national product.

However, the rise in the ratio for the two dissimilar groups of products, defense and consumer durables, is difficult to explain. It was noted earlier that the increases were concentrated in goods-in-process, which would imply a lengthening of the average production period in these two sectors. This might be reasonable in defense if the major increases had been in areas such as aircraft and missiles; but it is not immediately obvious that such an effect occurred in consumer goods, where the major increase is concentrated in nonautomotive durables.

A second hypothesis to explain the increase in the defense area is that it represents a pipeline effect in which production initially outruns shipments; but sales had leveled out by the middle of 1968 while inventories continued to rise. Nor is any such effect evident in machinery and equipment, where the ratio has declined slightly during a period of major expansion.

\section{Inventory Behavior and Sales Expectations}

The sales expectations and realizations of late 1966 and early 1967 throw light on the buildup of inventories during that period and offer a reassuring contrast with current experience.

A substantial portion of the initial 1966 buildup of stocks resulted from business overpredictions of durable goods sales in the last half of the year. The sales forecasts reported by durable goods manufacturers in the quarterly survey made by the Office of Business Economics shifted from an average quarterly underprediction of $\$ 1.6$ billion in 1965 and the first half of 1966 to an average overprediction of $\$ 2.4$ billion in the next year and a half. Forecast errors for nondurable sales also shifted substantially beginning in the fourth quarter of 1966. The change in the composition of sales of durables became increasingly important throughout 1967 and prevented any substantial decline in the overall inventory-sales ratio for durables.

In the current situation, the slowdown in total business sales in the first two months of 1970 suggests essentially no growth of sales between the fourth quarter of 1969 and the first quarter of 1970 . However, much of 
this slowdown was anticipated and inventories in general have increased only about half a billion dollars since December. Again this increase is concentrated in durable goods. There appears to be no serious inventory imbalance in nondurable goods.

Because the current slowdown was anticipated, durables inventories are not seriously out of line on the average. Virtually all of the accumulation relative to sales during the first two months of 1970 has been concentrated in the defense and consumer durables components of manufacturing. However, taken as a whole, consumer durables_- particularly autos-have had a substantial accumulation of excess inventories since the middle of 1969. This alone would imply a strong downward pressure on inventory accumulation throughout the first half of the year. In addition a continued gradual decline in defense expenditures should also exert significant restraint on inventories. But there seems to be little reason at present to expect an abrupt drop in this sector.

In general, recent developments are quite encouraging since they suggest that business will adjust to the sales slowdown without a major accumulation of excess inventories. I would tentatively conclude that the existing inventory excess in the consumer durables sector, together with a gradual decline in defense spending, will have a restraining influence on inventory investment throughout much of 1970 . But some of the factors identified above provide reassurance about the relatively high overall inventory-sales ratio of recent years. First, it is attributable in substantial part to a major shift in the composition of sales among durable goods manufacturing industries. Second, while the buildup of goods-in-process cannot be fully explained, it seems unlikely that these stocks could represent involuntary accumulation. Properly interpreted, the existing excess is not of a prerecession magnitude; and the anticipated nature of the current slowdown makes it improbable that such an excess will develop.

\section{Discussion}

Paul samuelson felt reassured by Bosworth's findings of no major excesses of inventory accumulation. But he pointed out that an inventory recession could still result from a general slowdown in final sales even without an initially excessive level of stocks. 
Several participants noted that it was impossible to show empirically that desired levels of inventory were directly responsive to monetary policy (although they were affected indirectly by the impact of monetary policy on final demand). Daniel Brill felt convinced by his own observations that the currently high cost of carrying inventory for automobile dealers was directly contributing to reduced stocks.

Alan Greenspan pointed to two problems of the data on stocks. First, private aircraft production is included in inventories of defense products. Current large-scale production of commercial jumbo jets may be swelling the defense inventory component. Second, since the book value of inventories lags behind prices while sales do not, inflation may pull down inventory-sales ratios. 